East African Journal of Science, Technology and Innovation, Vol. 1 (2): 2020.

This article is licensed under a Creative Commons license, Attribution 4.0 International (CC BY 4.0)

\title{
Analysis of gender parity in climate change adaptation actions within Kajiado and Kiambu counties, Kenya
}

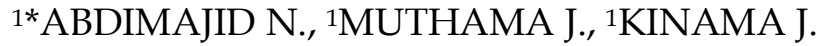 \\ ${ }^{1}$ Department of Meteorology, Wangari Maathai Institute for Peace and Environmental Studies, University of Nairobi \\ P.O.Box 30197, Nairobi \\ *Corresponding author: abdimajid@uonbi.ac.ke
}

\begin{abstract}
Kenya remains susceptible to climate change due to the dependence on rain-fed agriculture with limited climate change adaptation capacity. This study sought to establish the influence of gender roles on climate change adaptation in two different ago-climatic zones namely, Kajiado East and Central within Kajiado County in the arid part of Kenya and Kabete and Kikuyu within Kiambu County in the highlands region. A survey was conducted on 312 households, six gendered focus group discussions, and fourteen key informant interviews. Frequency analysis was used for descriptive statistics. Chisquare was used to test for statistical associations between variables $(p \leq 0.05)$. The findings showed that Kajiado County has experienced more climate change-related household food insecurity in comparison to Kiambu County. Only $12 \%$ of the respondents in Kiambu County indicated having experienced extreme household food insecurity related to climate change. The findings showed $66 \%$ of the respondents in Kajiado County considered herd mobility as the most important climate change adaptation strategy while in Kiambu $56 \%$ of the respondents considered changing of planting dates as the most important climate change adaptation strategy. Frequency analysis results indicated that there is more gender disparity in Kajiado than Kiambu County as shown by women having the least access and control over household land in both the rainy and extended drought periods. The gender disparity was confirmed by the chi-square test. Chi-square test results for full control of household land during the extended drought season in Kajiado county was $\left(\chi^{2}=102.3, \mathrm{df}=\mathrm{p} \leq 0.1\right)$. It was concluded that the autonomous nature of the adaptation strategies coupled with the influence of gender roles impedes achieving effective climate change adaptation strategies at the household level. There is a need for planned gender-sensitive adaptation actions to cushion local communities against climate change and enhance household food security.
\end{abstract}

Keywords: adaptation; climate change; gender; Kajiado; Kiambu

Cite as: Nunow Abdimajid, 2020. Analysis of gender parity in climate change adaptation actions within Kajiado and Kiambu counties, Kenya. East African Journal of Science, Technology and Innovation 1(2)

$\begin{array}{ll}\text { Received: } & 30 / 09 / 19 \\ \text { Accepted: } & 20 / 02 / 20 \\ \text { Published: } & 20 / 03 / 20\end{array}$

\section{Introduction}

The increased rainfall and temperature variations associated with climate change poses a great challenge to people's main livelihoods especially those dependent on agriculture and livestock (Thornton et al., 2007, Bryan et al., 2013). The agricultural sector is a major livelihood source for most susceptible populations across the world. In Africa, it is providing livelihood for millions of population, accounts for a significant portion of many countries' GDP while simultaneously providing employment opportunities to more than $60 \%$ of 
the entire labor force (Berger, 1989; Huq and Toulmin 2006; Kauti, 2009; Quiggin et., al 2010). And since women make up the majority of those living below the poverty line, they are more likely to bear the brunt of climate change more than everybody else.

The level of exposure, sensitivity, and capacity to adapt to changing climate varies across different agro-ecological zones. For example, Kajiado County and the greater arid and semiarid (ASAL) regions continuously remain affected by climate change and variability thus disrupting people's livelihoods (Ngaina and Mutai, 2013; Huho and Kosonei, 2014; Orindi et al., 2007). Kajiado County has experienced a wide range of rainfall anomalies over the periods which can be attributed to changing climate. Observations indicate low annual rainfall in several years, such as 1973, 1975, 1981, 1984, 1999, 2000, 2004, 2007, 2008 and 2011. The Maasai have their ways of interpreting or understanding atmospheric science. They observed wind and cloud movements, lightning, livestock, and wildlife movements to predict seasons. However, the increased rate of climate variability is making it difficult to rely on the traditional forecasting (Amwata, 2013). The trends are consistent with what was observed by ICPAC (2007), Amwata (2013) and Opiyo (2014) in the ASALS regions of Kenya. The extended drought associated with climate change led to conflicts between pastoralist communities such as Maasai, Turkana, Samburu, and also with neighboring farming communities in competition for pasture and water. Post-harvest losses have also been observed due to increased pest and diseases associated with climate change in the region (Recha and Omondi 2012).

Over the last century, Kiambu region has experienced a mean temperature rise at a rate of $0.005^{\circ} \mathrm{C}$ per year from 1929 to 2009 (Jaramillo et al., 2013). An accelerated climate change-related temperature rise was observed from the year 1991. The county received its highest recorded precipitation in the years 1997, 2006 and 2010 due to the influence of the El Nino effects in the region (Jaramillo et al., 2013). Climate changerelated temperature and rainfall variability have led to disruption of crop production associated mainly with coffee and tea which generates billions of shillings. For example, in the year 2013 , the tea sector alone injected nearly $\$ 1.3$ billion to Kenya's economy. In 2012, low temperatures led to widespread frost affecting the tea estates leading to loss of one-third of the tea harvested in that year (KALRO, 2012). Also, increased climate change-related pest and diseases continuously affects coffee production leading to loss in total production expected by local farmers and risking availability of ready markets in European which requires continuous production (Pascual et al., 2006; Jaramillo et al., 2011).

Adaptation to climate change requires individuals or households to have the ability to combine a variety of options to adjust effectively. However, increased frequencies of droughts and floods is weakening the potential of local communities to cushion themselves against the vagaries of climate change. Furthermore, climate change has a genderdifferentiated impact (IPCC, 2014). To sustain themselves, people utilize their physical environment, economic, political and socialcultural resources. However, these systems have different levels of vulnerabilities depending on the status of individual gender in relation to the system. According to Alston (2013), in most African communities, livelihood resources such as access to water, land, credits, political power, income and safety nets are usually controlled by specific individuals or entities. People who are already poor and marginalized in terms of access to resources, political representations and/or due to gender roles are likely to have fewer adaptation options (Mitchell et al., 2007). The gender inequality can be addressed using alternative approaches including participatory technique in decision making, labour, and control of household resources (Oberhauser and Johnston-Anumonwo 2014). Deliberate government policies such as giving women more power in the land restitution process can reduce gender inequality. A good example is Ethiopia's state policies, changes in the Family Code implemented in 2000 and communitybased land registration, undertaken since 2003 leading to improved gender equity (Kumar and Quisumbing (2015).

Climate change-related changes in the biophysical environment, such as flooding, frequent droughts, and water shortages can lead to loss of livelihood and increased poverty, especially among the majority rural poor women populations (Christensen et al., 2007; Ibarrarán et al., 2009). Their limited capacity to adapt to the changing climate coupled with the 
negative influence of gender roles in the implementation of adaptation options is likely to affect efforts towards food security, Vision 2030, and sustainable development.

Sub-Saharan Africa, Kenya included is losing an average of \$US95 billion a year due to gender inequality (Carrasco, 2016). Gender, Agrobiodiversity, and Climate Change by Bhattarai et al., (2015), addressing the interlinkages between climate change and gender concludes existence of a perception in most developing nations in which climate change is seen as a distant or separate from everyday realities of making decisions and the structures that interact to reinforce system-wide historical and currently social inequities. Further analysis of the influence of gender parity in climate adaptation actions in Kajiado and Kiambu counties will shade more light on the effects of gender roles on climate change adaptation and household food security.

\section{Materials and methods}

\section{Research design and data collection}

This study employed a cross-sectional survey design using both qualitative and quantitative methods. It was undertaken between September 2017 to December 2017 covering Kabete and Kikuyu sub-counties in Kiambu County and Kajiado East and Kajiado Central Sub-counties in Kajiado County. The study areas in the two counties were selected due to differences in agro-ecological zones. Both structured and semi-structured questionnaires were applied to collect data from respondents of both genders above 18 years of age. Stratified systematic random sampling was used to identify households to be interviewed. Areas that had a combination of both urban and rural settings were identified using approaches including population density, land uses, infrastructure, isolation, and distinct socio-cultural milieus. (Hart et al., 2005). The study sites consisted of Kajiado East and Kajiado Central within Kajiado County and Kabete and Kikuyu within Kajiado County.

According to the 2009 population census, Kajiado East and Kajiado central had a combined total population of 239,460 while Kabete and Kikuyu sub-counties had 373,658 people. The total population was 613,118 , of which the sample size chosen has a 95\% confidence level and 5.55\% margin of error. 156 households were chosen from each county using formula by Taro (1967) which translated to a sample size of 312 households. Purposive sampling was applied in selecting the target respondents for the key informant interviews (KII) and focused group discussions (FGD).

Chi square $\left(\chi^{2}\right)$ was used to study the difference between observed and expected data values (McHugh, 2013).

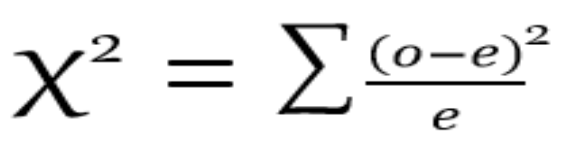

Where

$$
\begin{aligned}
& \mathrm{O}=\text { Observed frequency, and } \\
& \mathrm{e}=\text { Expected frequency }
\end{aligned}
$$

\section{Study Areas}

Two counties, namely Kajiado and Kiambu Counties constituted the geographical scope of the study.

\section{Kajiado County}

Kajiado County borders Nairobi to the north and covers $21901 \mathrm{~km} 2$ area. The county population stood at 1,117,840 with 557,098 male and 560,704 females (GoK, 2019). It is part of the ASAL region of Kenya making up 80 percent of total landmass. It receives an average rainfall ranging from $300-800 \mathrm{~mm}$ each year in a sporadic pattern. The county is dominated by arid to semi-arid grasslands, rocky thorn bushlands, acacia woodlands, marshlands and swamps. The major soil types consist of sandy soils, brown calcareous clay loams and pumice soils in higher elevated areas and poorly developed clay soils in the floodplains (Ogutu et al., 2014). Majorly, the county falls within agroclimatic Zone V (semi-arid) and Zone VI (arid), with Zone $\mathrm{V}$ receiving annual rainfall between 450 and $800 \mathrm{~mm}$ while Zone VI receives significantly less rainfall. Only 8 percent of the county land has good potential for rain-fed agriculture, mostly in the Athi-Kapiti Plains thus making pastoralism and agro-pastoralism the ideal for such conditions.

The majority of the inhabitants in Kajiado County are the Maasai community who practice pastoralism as the main livelihood source. The main livestock breeds are cattle including Zebu, Sahiwal, Exotic and Boran. Goat breeds include Galla, german alpine and small east African. The 
main sheep breeds include Dorper and red Maasai (KCIDP, 2018-2022). Also, wildlife and farming activities contribute to the economy of the county. Figure 1 shows the map of Kajiado County.

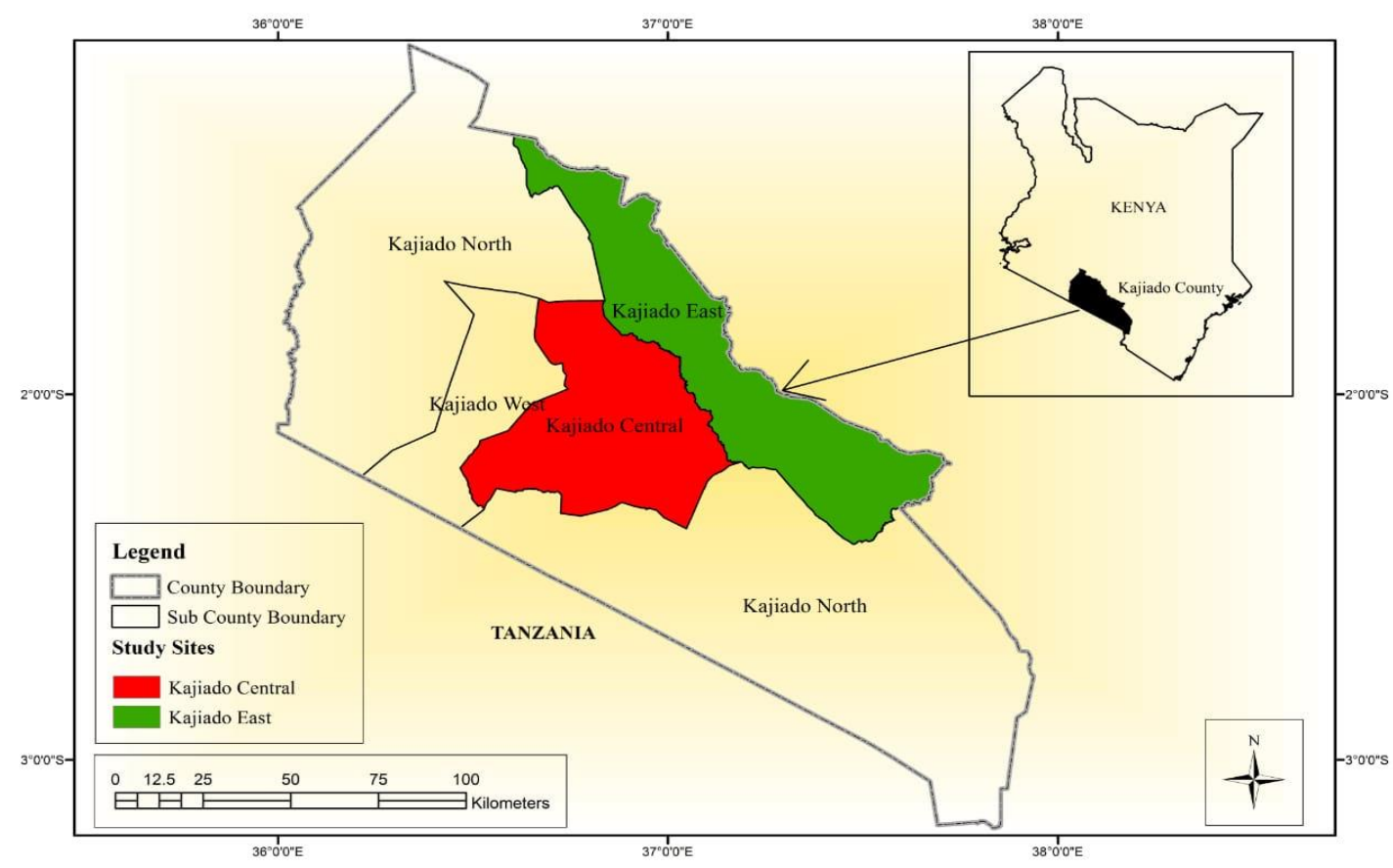

Figure 1: Map of Kajiado County showing the study areas.

\section{Kiambu County}

Kiambu County covers 2,543.5Km2 area between latitudes $0025^{\prime}$ and $1020^{\prime}$ South of the Equator and Longitude 360 31'and 370 15`East. The County population stood at $2,417,735$ people with 1,187,146 male and 1,230,454 females (GoK, 2019). According to the Kiambu County Integrated Development Plan (CIDP) 2018-2022, it receives bi-modal type of rainfall averaging $1,200 \mathrm{~mm}$ and a mean temperature of $26^{\circ} \mathrm{C}$, the total arable land stood at $1,878.4 \mathrm{Km} 2$ of which cash crops account for 35,367.41 Ha and 21,447 Ha utilized for food crops. There are three main types of soils in the area, namely, volcanic footbridges soils, high-level upland soils and plateau soils. The volcanic footbridges soils with moderate fertility covers much of the County and are mostly suited for coffee and tea production. The high-level upland soils are found mostly in Githunguri, Gatundu, Kabete Kiambaa and Kikuyu. The soils are from volcanic rocks and are known to be the most fertile soils that support livestock and agricultural production including growth of horticultural products, coffee, tea, pyrethrum, maize among others. Low fertile soils are mainly found in Thika town, Juja and Ruiru area. The soils are mostly sand or clay and are conducive for drought-resistant crops such as soya beans and ranching. The main forest types in the county are natural and plantation forests. The natural gazetted forests produce products including electricity transmission poles, firewood, and timber for construction while plantation forests which are mostly privately owned produce timber, charcoal, fruits among others.

The county falls under agro-ecological zone I to III which makes it conducive for agriculture. Coffee and tea make the major cash crops while Irish potatoes, maize, banana, arrow roots, vegetables, and pineapples make the main food crops (Musa and Odera 2015). Figure 2 shows the map of Kiambu County. 


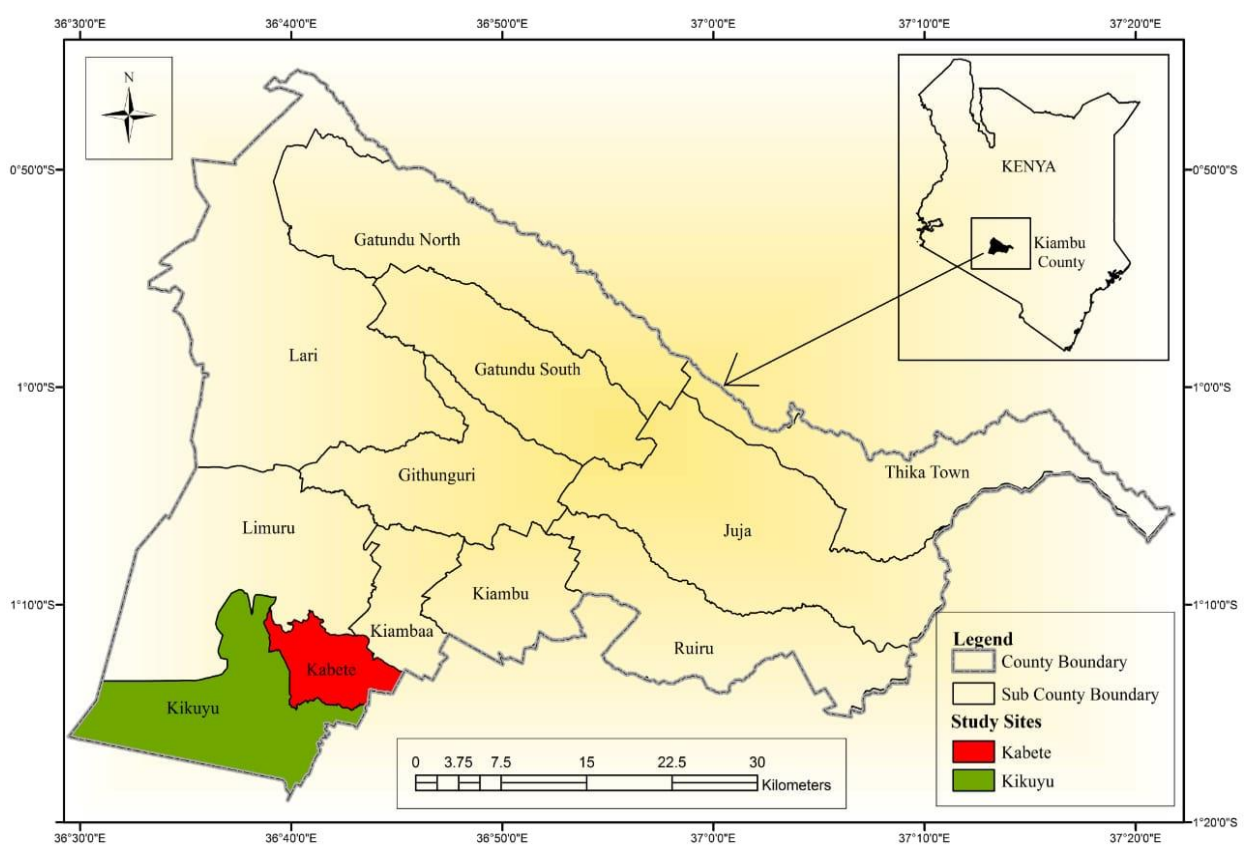

Figure 2: Map of Kiambu County showing the study areas.

Source: Author 2019

\section{Data analysis}

Frequency analysis was used for descriptive statistics. Chi-square was used to test if significant differences existed in local perception of climate change-related vulnerabilities in Kajiado and Kiambu Counties and difference in access and control of household land during rainy and extended drought seasons between men and women in both Kajiado and Kiambu counties.

\section{Results}

\section{Climate change-related vulnerabilities}

The various climate change-related vulnerabilities identified by the respondents were listed in Figures 3 and 4 below. Majority of the respondents in Kajiado County agreed with the statements that climate change-related increased pest and diseases, decreased water and fodder availability, increased loss of livestock and crops was experienced in the last few years. According to figure 4, respondents in Kiambu County identified climate changerelated increased incidence of pests and diseases as shown by $22.4 \%$ agree and $74.4 \%$ strongly agree and increased loss of crops as shown by $53.2 \%$ agree and $41 \%$ strongly agree. However, the p-values obtained are greater than 0.05 in all the cases indicating there was no significant difference in perception of climate changerelated vulnerabilities in Kiambu and Kajiado counties as presented in Table 1 below. 


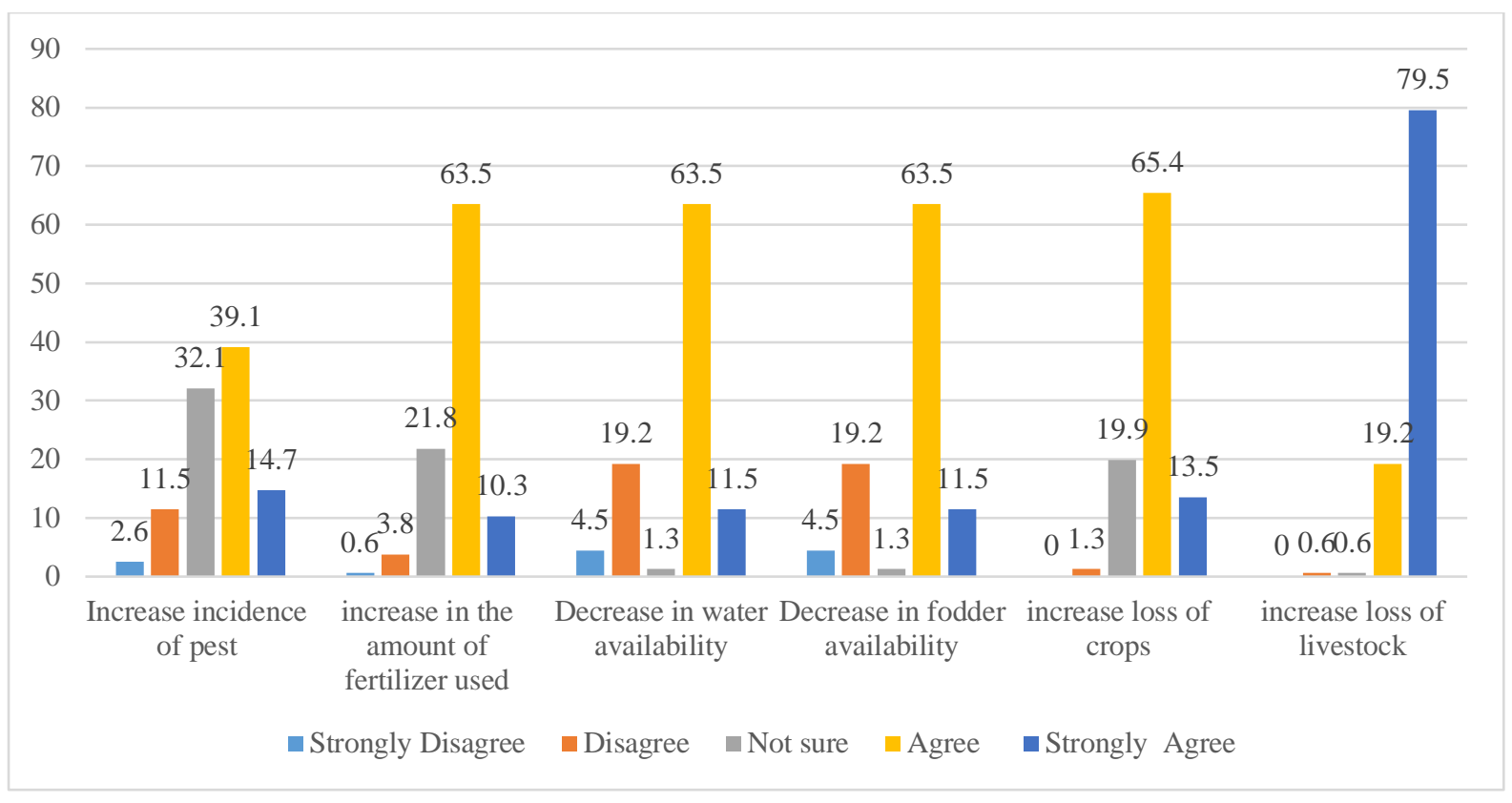

Figure 3. Local perception on climate change-related vulnerabilities in Kajiado County

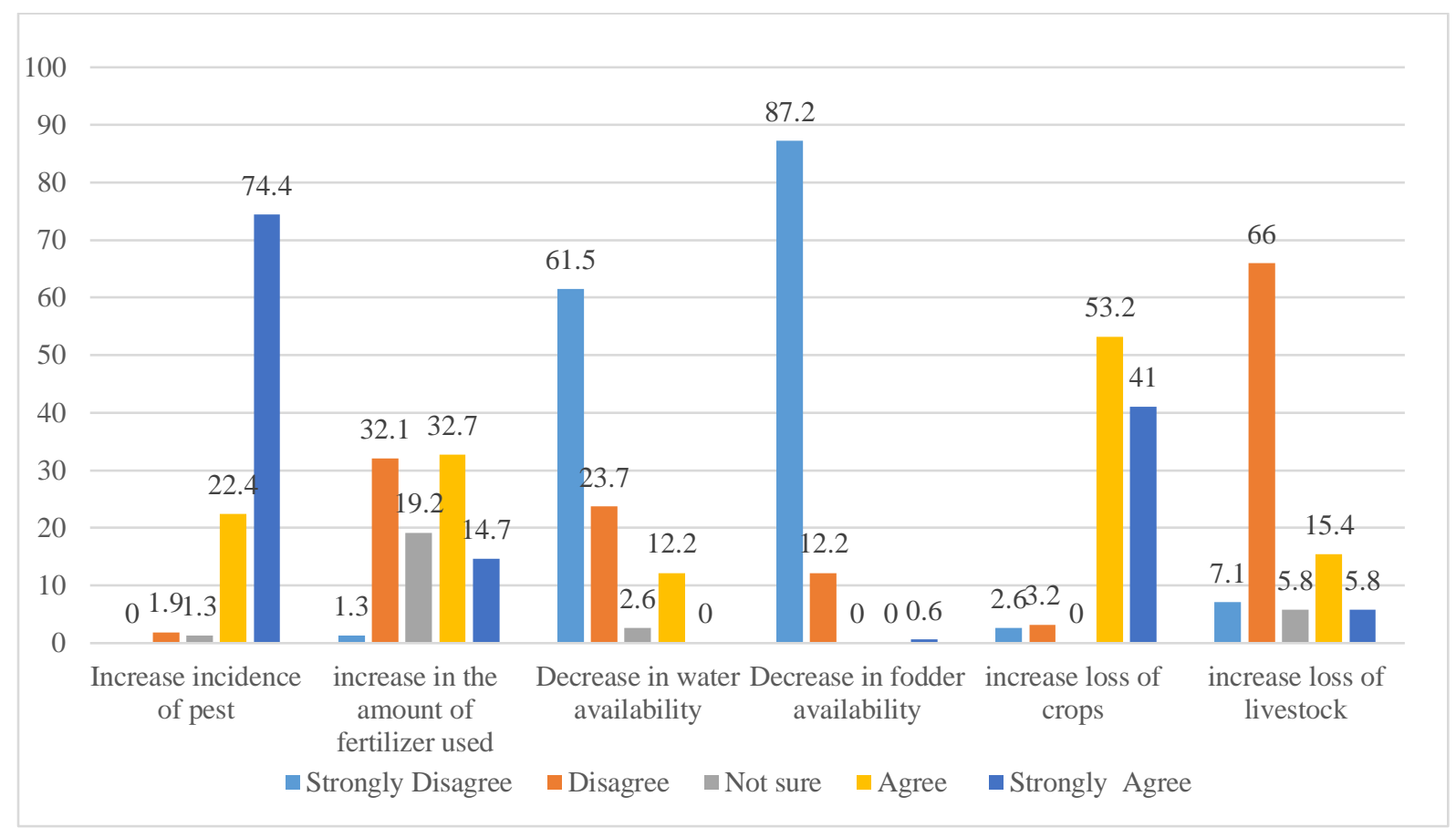

Figure 4. Local perception on climate change-related vulnerabilities in Kiambu County Source: Author, 2019 
Table 1: Chi-square test results of perception on climate change related vulnerabilities

\begin{tabular}{lccc}
\hline & Chi-square value & df & P-value \\
\hline Increase in incidences of pests & 10.513 & 12 & 0.5711 \\
Increase in the amount of fertilizers & 14.591 & 16 & 0.5548 \\
use & 9.373 & 12 & 0.671 \\
Decrease in water availability & 13.972 & 8 & 0.082 \\
Decrease in fodder availability & 4.013 & 9 & 0.911 \\
Increased loss of crops & 14.590 & 12 & 0.265 \\
Increased loss of livestock & & & \\
\hline
\end{tabular}

Impact of climate change on household food security

According to Table 2 below, $46 \%$ of the respondents in Kajiado County experienced extreme food shortages due to climate changerelated extended drought periods while in
Kiambu County $12 \%$ experienced extreme food shortages related to changing climate. However, more people in Kajiado County experienced food shortages in the last few years in comparison to their counterparts in Kiambu County.

Table 2 Impact of climate change on household food security

\begin{tabular}{lcccc}
\hline & Kiambu County & \multicolumn{3}{c}{ Kajiado County } \\
\hline & Frequency & Percentage & Frequency & Percentage \\
Very extreme & 0 & 0 & 14 & 9 \\
Extreme & 18 & 12 & 72 & 46 \\
Normal & 1 & 1 & 47 & 30 \\
N/A & 137 & 77 & 23 & 15 \\
Total & $\mathbf{1 5 6}$ & $\mathbf{1 0 0}$ & $\mathbf{1 5 6}$ & $\mathbf{1 0 0}$ \\
\hline
\end{tabular}

\section{Climate change adaptation strategies}

According to the results from Table 3 below, both communities in Kajiado and Kiambu undertook adaptation strategies to cushion themselves against changing climate. In Kajiado County, $66 \%$ of the respondents considered herd mobility as the biggest adaptation strategy, $20 \%$ indicated livelihood diversification, 9\% indicated buying hay while 5\% indicated destocking as their major adaptation strategy. In Kiambu County, $56 \%$ of the respondents identified Change of planting dates as the major adaptation strategy against climate change, $23 \%$ indicated irrigation, and $12 \%$ mentioned growing of drought-tolerant crops as a critical adaptation strategy to maintain house-hold food security while $9 \%$ identified livelihood diversification as a way of increasing their resilience against climate change. 
Table 3: Climate change adaptation strategies applied during extreme rainfall and temperature variations in Kajiado and Kiambu Counties

\begin{tabular}{|c|c|c|c|c|}
\hline Challenge & Adaptation strate & & & \\
\hline \multirow{5}{*}{$\begin{array}{l}\text { Extreme rainfall and } \\
\text { temperature variations }\end{array}$} & Kajiado County & Percentage & Kiambu County & Percentage \\
\hline & Herd mobility & $66 \%$ & Change of planting & $56 \%$ \\
\hline & $\begin{array}{c}\text { Livelihood } \\
\text { diversification }\end{array}$ & $20 \%$ & irrigation & $23 \%$ \\
\hline & Buying hay & $9 \%$ & $\begin{array}{l}\text { Drought tolerant } \\
\text { crops }\end{array}$ & $12 \%$ \\
\hline & Destocking & $5 \%$ & $\begin{array}{c}\text { Livelihood } \\
\text { diversification }\end{array}$ & $9 \%$ \\
\hline
\end{tabular}

\section{Gender roles in the implementation of adaptation options}

\section{Chi-square test}

The chi-square analysis results of the influence of gender on access and control of household lands in the face of changing climate are shown in Tables 4 to 6 . In Table 4, women in Kajiado have the least access to household land during the extended drought seasons and rainy seasons in comparison to women in Kiambu as shown by comparative percentage difference of $-82 \%$ during rainfall seasons and $-82 \%$ during the extended drought periods respectively. The null hypothesis was 'Men and women have equal access to household land during rainy seasons', and 'Men and women have equal access to household land during extended drought season', respectively. Also, the result indicates that women in Kiambu have more control over the household land in comparison to their counterparts in Kajiado as shown by $-12 \%$ and $12 \%$ difference during the rainy seasons and drought periods respectively. In this case, the null hypothesis was 'Men and women have equal control of household land during rainy seasons' and 'Men and women have equal control of household land during extended drought season', respectively. However, in both counties, there was gender disparity in access and control of land for all the seasons considered as confirmed by the chi-square test, through rejection of the hypothesis in Tables 5 and 6 for example, the chi-square test results for full control of household land during the extended drought season in Kajiado county was $\left(\chi^{2}=102.3, \mathrm{df}=\mathrm{p} \leq 0.1\right)$. All the $\mathrm{p}$-values obtained are much less than 0.05 . We, therefore, reject the null hypothesis and conclude that there is a difference in access to household land between men and women in all the seasons considered. 
Table 4: Comparative analysis of gender roles in the implementation of adaptation options between Kiambu and Kajiado Counties

\begin{tabular}{|c|c|c|c|}
\hline Item & Gender & Season & $\begin{array}{c}\text { Comparative \% } \\
\text { difference relative to } \\
\text { Kajiado }\end{array}$ \\
\hline & Men & Rainy Seasons & +10 \\
\hline \multirow{4}{*}{$\begin{array}{l}\text { Full access to household } \\
\text { land }\end{array}$} & & Extended drought seasons & -28 \\
\hline & Women & Rainy Seasons & -82 \\
\hline & & Extended drought seasons & -82 \\
\hline & Men & Rainy Seasons & +37 \\
\hline \multirow{3}{*}{$\begin{array}{l}\text { Full control of household } \\
\text { land }\end{array}$} & & Extended drought seasons & +20 \\
\hline & Women & Rainy Seasons & -12 \\
\hline & & Extended drought seasons & -12 \\
\hline
\end{tabular}

Table 5: Chi-square test results of difference in access and control of household land between men and women in all the seasons for Kiambu County

\begin{tabular}{cccccc}
\hline & & $\begin{array}{c}\text { Chi-square } \\
\text { value }\end{array}$ & df & P-value & Remark \\
\cline { 2 - 5 } & Rainy seasons & 226.7 & 9 & $2.2 \times 10^{-16}$ & $\begin{array}{c}\text { Unequal } \\
\text { access }\end{array}$ \\
$\begin{array}{c}\text { Full access to household } \\
\text { land }\end{array}$ & $\begin{array}{c}\text { Extended drought } \\
\text { seasons }\end{array}$ & 218.8 & 9 & $2.2 \times 10^{-16}$ & $\begin{array}{c}\text { Unequal } \\
\text { access }\end{array}$ \\
$\begin{array}{c}\text { Full control of } \\
\text { household land }\end{array}$ & $\begin{array}{c}\text { Rainy seasons } \\
\text { Extended drought } \\
\text { seasons }\end{array}$ & 149.5 & 9 & $2.2 \times 10^{-16}$ & $\begin{array}{c}\text { Unequal } \\
\text { control } \\
\text { Unequal } \\
\text { control }\end{array}$ \\
\hline
\end{tabular}


Table 6: Chi-square test results of difference in access and control of household land between men and women in all the seasons for Kajiado County

\begin{tabular}{|c|c|c|c|c|c|}
\hline & & $\begin{array}{l}\text { Chi-square } \\
\text { value }\end{array}$ & $\overline{d f}$ & P-value & Remark \\
\hline \multirow{2}{*}{$\begin{array}{l}\text { Full access to } \\
\text { household land }\end{array}$} & Rainy seasons & 174.0 & 9 & $2.2 \times 10^{-16}$ & $\begin{array}{c}\text { Unequal } \\
\text { access }\end{array}$ \\
\hline & $\begin{array}{c}\text { Extended drought } \\
\text { seasons }\end{array}$ & 246.1 & 9 & $2.2 \times 10^{-16}$ & $\begin{array}{l}\text { Unequal } \\
\text { access }\end{array}$ \\
\hline \multirow[t]{2}{*}{$\begin{array}{l}\text { Full control of } \\
\text { household land }\end{array}$} & Rainy seasons & 120.3 & 9 & $2.2 \times 10^{-16}$ & $\begin{array}{l}\text { Unequal } \\
\text { control }\end{array}$ \\
\hline & $\begin{array}{c}\text { Extended drought } \\
\text { seasons }\end{array}$ & 102.3 & 9 & $2.2 \times 10^{-16}$ & $\begin{array}{l}\text { Unequal } \\
\text { control }\end{array}$ \\
\hline
\end{tabular}

Perception on gender-sensitive climate change adaptation measures

Breaking from defined gender roles

According to Figures 4 and 5 below, $23 \%$ of the respondents from Kiambu strongly agreed breaking from defined gender roles can contribute to improved community adaptive capacities while $75 \%$ of the respondents agreed with the same statement. In Kajiado County, $21.8 \%$ of the respondent strongly agreed that breaking from defined gender roles can contribute to improved community adaptive capacities while $59 \%$ of the respondents agreed to break from defined gender roles contributed to improved community climate change adaptation capacities.

\section{Climate change adaptation training}

In Kiambu County, $82.6 \%$ of the respondent agreed that climate adaptation training was accessible to both men and women while in
Kajiado $46.2 \%$ agreed that climate adaptation training was accessible to both men and women. However, in Kajiado County, $24.4 \%$ of the respondents disagreed with the statement that Climate adaptation training was accessible to all people regardless of gender. This has also been confirmed by some respondents from the focus group discussions stating whenever training opportunities availed it was mostly men that made the majority of the participants in comparison to women who were usually busy with domestic labour.

\section{Climate information}

In Kiambu, $80.1 \%$ of the respondents agreed that climate information was available to all community members regardless of their gender while in Kajiado $39.1 \%$ agreed that climate information was available to all without gender bias and $30.8 \%$ of the respondents disagreed with the same statement. 


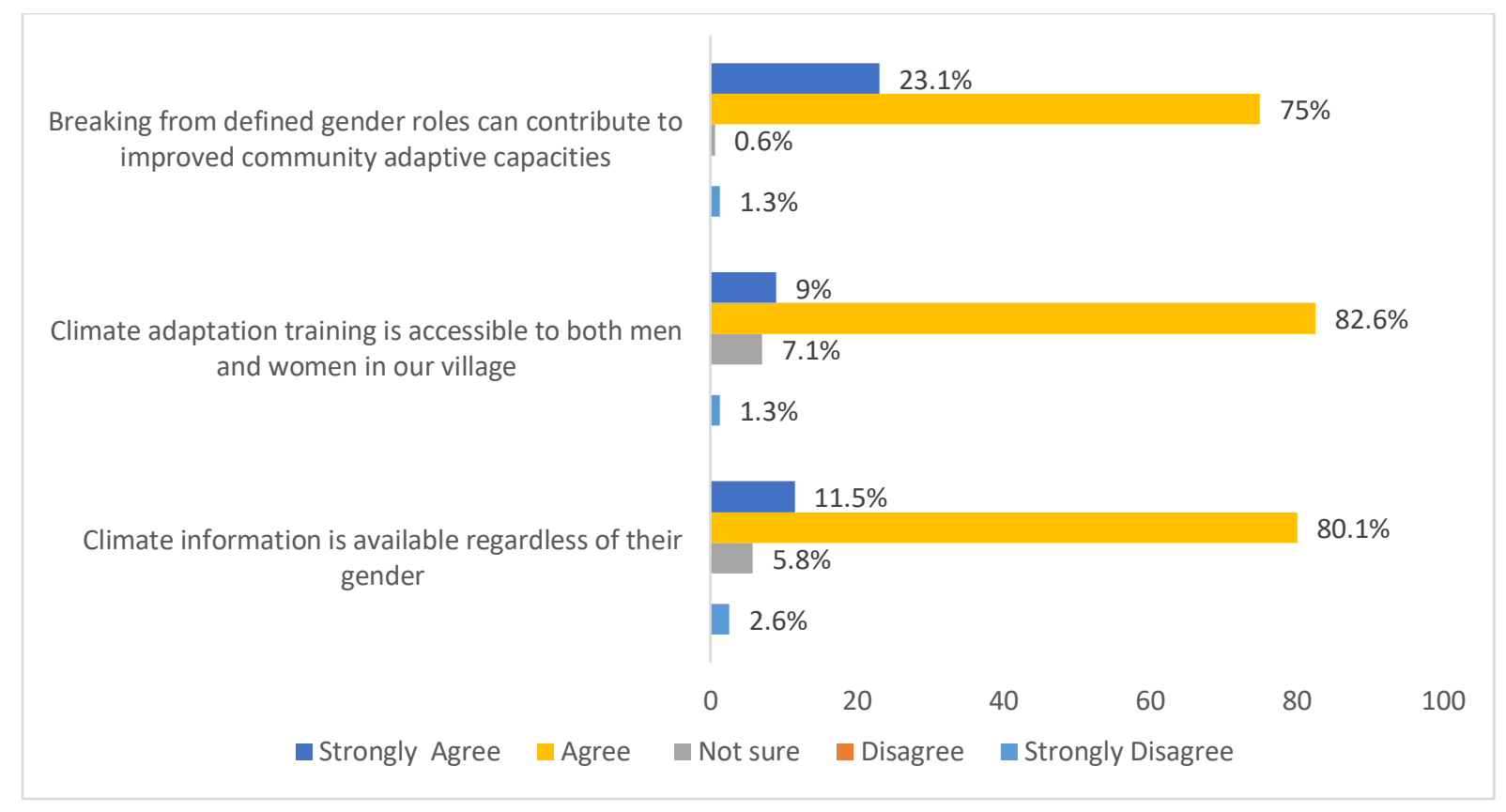

Figure 5: perception of the respondent on statements relating to gender sensitive climate change adaptation measures in Kiambu County

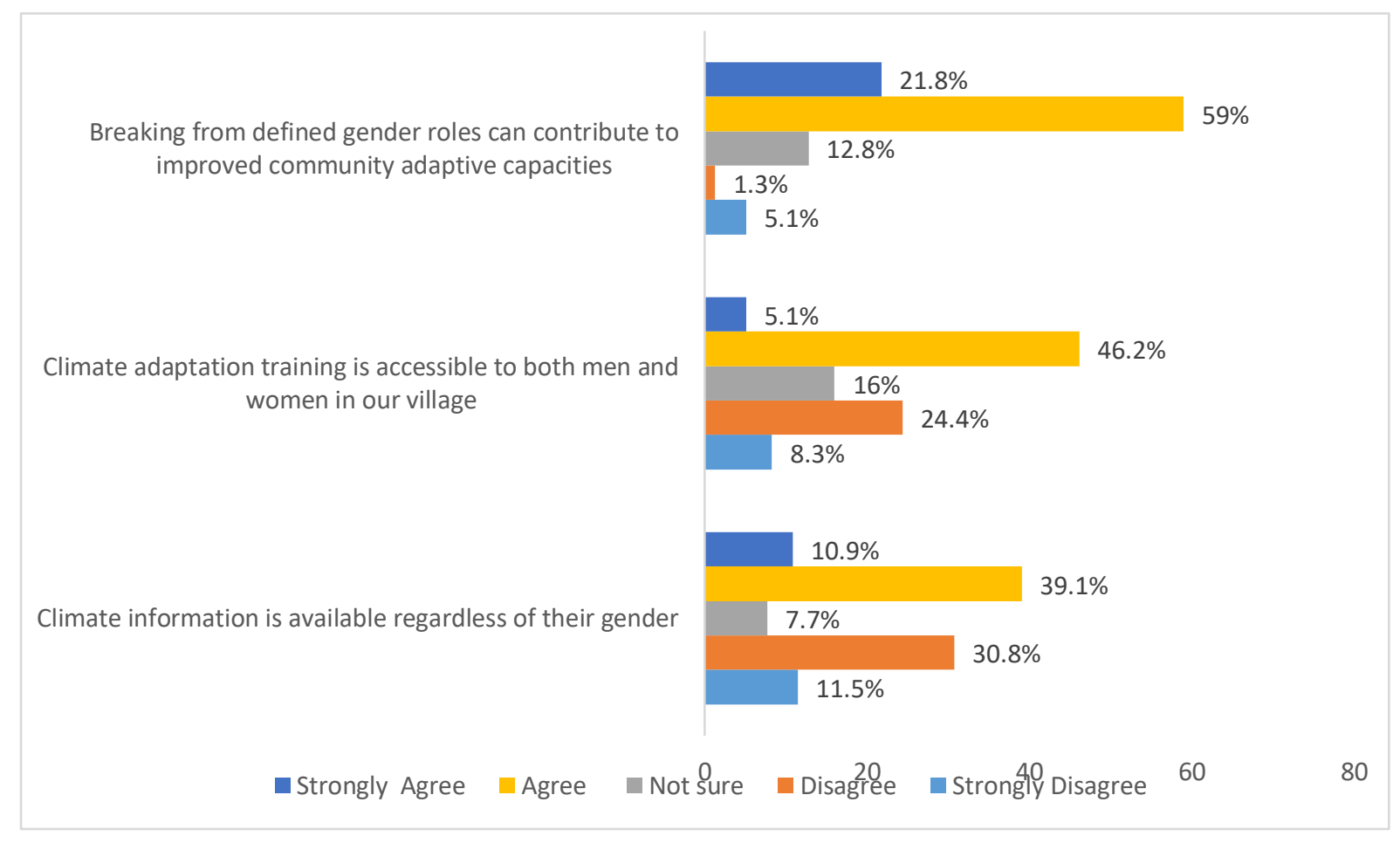

Figure 6: perception of the respondent on statements relating to gender sensitive climate change adaptation measures in Kajiado County. 


\section{Discussion}

Climate change-related vulnerabilities in Kajiado and Kiambu County indicated perceived increased loss of livestock and crops, water shortage, loss of fodder and increased incidence of pest and diseases in Kajiado while increased pest and disease and loss of crops have been experienced in Kiambu County. The high prevalence cases of climate change-related pests and disease and crop losses in Kiambu and the greater Central region has been cited by other studies as well (Kuria, 2009; GoK, 2010; Macharia et al., 2012). The respondents in Kiambu County disagreed with their counterparts in Kajiado on a decrease in water availability, fodder, and loss of livestock. This implies that the pastoral communities in Kajiado were more exposed to climate shocks than the majority of farming communities in Kiambu County since its part of the ASAL regions known for low rainfall potential and high temperatures. Climate change has further exacerbated the situation making the local populations more vulnerable by exerting pressure on the livelihoods hence increased in poverty levels (Orindi et al., 2007; Christensen et al., 2007; Hoffmann, 2010; GoK, 2010; Ngaina and Mutai, 2013; Darkoh et al., 2014).

More negative impact of climate change on household food security is experienced in Kajiado County than Kiambu County. This has been well summarized by one of the respondents from the women Focus Group Discussions in Kajiado County stating; "nowadays it has become hard to get food.... you find that one packet of Unga (wheat flour) goes for 200 shillings, sugar goes for 160 per $\mathrm{kg}$ and tea leaves for 60 shillings.... when you go to the shop with 1000 shillings, you only buy 2 packets of Unga, a kilogram of sugar and a kilo of rice which is not enough for my children..... It's only God for us now because this drought has become too much... So my children got little food to sustain themselves to go to school and back". Kajiado is part of ASAL Counties in Kenya where climate change impacts are more severe while (Orindi et al., 2007; GoK, 2010; Fraser et al., 2011) Kiambu is part of the highland regions of Kenya falling under the agroecological zones I to III. The region has more favorable soils and climatic conditions that can support agriculture hence household food security (Jaetzold and Schmidt 1983).

According to the Key informant interviews in Kajiado County, climate change-related extended drought periods have put more pressure on the already vulnerable pastoral communities through the loss of livestock. This has resulted in dependence on importation of food items such as maize, beans, vegetables among others from nearby Counties thus leading to increased prices of basic food items. However, the availability of food in the market did not mean the majority of the households were able to afford hence the increased number of households that were forced to skip meals including children and the elderly. The perception of food insecurity among the key informant interviews in Kajiado County is supported by Amwata et al., 2015 stating the inability of nearly 70 percent of people in ASALs of Kenya including Kajiado operating below the poverty line and remaining dependent on existing social structures. The difference in the level of poverty in the two counties also points to the existence of more resilience structures in Kiambu than in Kajiado County hence less vulnerable. Kiambu County has the lowest poverty index in Kenya only second to Nairobi County contributing 11.1 percent to the national wealth while the poverty index ranking put Kajiado County position 11 out of the 47 Counties in Kenya. The contribution of Kajiado County to the national wealth has been rated at only 3.8 percent which is less significant in comparison to Kiambu County even though they are both close to the capital city, Nairobi (KNBS and SIDS, 2013).

Both communities in Kajiado and Kiambu Counties are involved in climate change adaptation strategies with herd mobility and change of planting dates as the major climate change adaptation strategies respectively. The suitability of pastoralism as a major source of livelihood for communities in Kajiado and the greater ASAL is due to its mobility advantage during the face of climate change. The preference of livestock production in ASAL parts of Kenya has been observed by other studies (Swift, 1998; Fratkin and McCabe1999; Wasonga, 2009; Wasonga et al., 2010; Orindi et al., 2007). Farming is the main source of livelihood for the majority of the people in 
Kiambu hence the need to adjust in the face of changing climate (Murage and Ilatsia 2011; Njuguna and Nyairo2010). Although both local farmers and pastoralists are adapting to climate change, increased climate variability continues to be a challenge in sustaining adaptation options such as herd mobility and changing of planting dates. Therefore, it is recommended to adopt climate-smart best practices to bolster resilience against the vagaries of climate change. These include irrigation, diversification of enterprises, integrated pest management, biodiversity management, sustainable mechanization, integration of traditional weather focus and scientific methods to provide reliable weather focus, agro advisories climate analog, adoption of crop and livestock insurance schemes. (Alexander, et al., 2011; Nyasimi, et al., 2014).

Frequency analysis results point to more gender disparity in Kajiado than Kiambu County as indicated by women having the least access and control over household land in all seasons. The inability of women from the Maasai community to have more access and control over household resources such as land has been rooted in the patriarchal nature of their traditional system. In the Maasai community, gender roles are shaped through the lens of its customs. Men usually belong to an age-set system which gives a platform to voice their concerns about wider issues affecting them or the community. However, women do not belong to age groups or any democratic setting recognized within the customary law. According to Talle (2007), the social age-set system is a man affair where appointments and delegations are done solely by men. This customary power system has been applied traditionally in sharing and subdivision of landholdings among the Maasai elders, both rich and poor herders, and the youth. Since women were locked out of these opportunities coupled with the inability to challenge their exclusion, it has entrenched a culture of dependence on men thus creating unequal gender dynamics in terms of access, control and critical decision making at household levels (Meinzen-Dick and Mwangi, 2009). On the other hand, the Kikuyu community had a patriarchal system where men were considered to be the head of the household automatically. In case of death of the father, the eldest son assumed the role (Muriuki 1974). Girls, women and uncircumcised boys were responsible for performing domestic/household duties. Once circumcised, boys were considered 'men' and qualified to be exempted from such tasks. This cemented men's authority at household levels and was exploitatively used to gauge 'good wife' by the level of obedience to their husbands (WamueNgare and Njoroge 2011). According to Kenyatta (1938), women had no ownership rights to land, livestock and/or valuable assets. They were allowed to access and control household goods such as pans, baskets, utensils, pots, and milk. Even if women worked on the farms and generated income from selling the produce, they were still bound to send the profits to their husbands even if they worked outside the area of residence. This means it was a system of dominance where women were marginalized in resource ownership, labor divisions, and decision making.

However, the gender dynamics among the Kikuyu men and women shifted around the 1980 's when Kenya experienced economic deterioration. This was a result of external shocks especially falling oil prices of the late seventies. These led to high rates of inflation in the country resulting in deliberate government policies such as massive layoffs to keep its economy remain afloat. As men dominated the formal sector jobs, they were significantly affected in comparison to their female counterparts thereby rendering most of them jobless. As gender roles are specified in the Kikuyu household setting, it became a nightmare for men to switch smoothly to the informal sector since it was women's territory. Women including those that were laid off took care of domestic responsibilities and also slowly filled gaps left by the men who drained their slow self-esteem on illicit brews after losing prestige in the eyes of their families and general society. Importantly, this period coincided with the 1985 UN women conference held in Nairobi which discussed pushing women agenda forward all over the world. As the debate on gender equality was taking shape around the world, at local level change was in the air too. Kiambu Women become more enterprising with the adoption of Chamas (women groups) which made access to loans easier than before. They became more independent and broke societal barriers that prevented them from owning resources, defining roles and also curtailing their ability to make decisions that affected their families, However, because of the strong cultural influences which stayed for long 
periods, gender equality has not been fully realized in Kiambu County since critical resources especially land ownership is dominated by men (Wamue-Ngare and Njoroge 2011).

The study indicates that respondents in both Kiambu and Kajiado County perceived defined gender roles have the potential to be a stumbling block to development since it gives men and women unequal opportunities in access and control of household resources such as land while faced with the same challenges including climate change. A previous study by WamueNgare and Njoroge (2011), agrees that gender dynamics in Kiambu have improved in the last few decades. Also in Kajiado County, there have been observed changes although not at the same level as in Kiambu County. Majority of the respondents from the key informant interviews agreed that gender inequality in Kajiado county has been showing slow improvement in the last decade due to the combined efforts of the National and County government emphasizing the need to incorporate women in all spheres of decision making and affirming their rights as enshrined in the constitution. Women possess unique skills and experiences that can enhance the resilience of the household against the vagaries of climate change if provided with critical resources including information, technology, decision-making abilities and control of resources. In cases where women were involved in natural resource management, it has been found that they do not only contribute to sustainable management of the resources but increase incomes for the group (Agarwal, 2001, 2009; Upadhyay et al., 2005; Mwangi et al., 2011).

\section{Conclusion}

The analysis of gender disparity in access and control of household land and its influence on climate adaptation strategies in Kajiado and Kiambu counties indicated that there was no significant difference in perception of climate change-related vulnerabilities. Climate changerelated household food insecurity was experienced more in Kajiado County than in Kiambu County. Local communities in Kajiado are already adapting to climate change with strategies such as herd mobility, destocking and livelihood diversification including kitchen gardening, selling herbs, clothes, beads, and goats rearing. However, due to their autonomous adaptation strategies, the majority of pastoralists struggle to enhance their resilience hence increased in poverty levels. There is a need to adopt climate-smart practices including water harvesting, biodiversity management, irrigation, integration of traditional and scientific weather focus, integrated pest management and adoption of crop and livestock insurance schemes. There was a low level of gender disparity in Kiambu County in comparison to Kajiado County hence less negative effects on climate change adaptation strategies adopted at the household level. The invisible social-cultural dynamics derail efforts towards women empowerment who make up a significant number of the poorest sections of society. Without enhancing their socio-economic status through gender equity in decision making, access, and control of resources, climate adaptation capacity would remain vulnerable and ineffective hence hampering efforts towards food security and sustainable development. Therefore, planned gender-sensitive adaptation strategies should be encouraged to enhance the capacity of individual household's to build resilience to climate change.

\section{References}

Agarwal, B., 2001. Participatory Exclusions, Community Forestry, and Gender: An Analysis for South Asia and a Conceptual Framework. World Development, Vol. 29, No. 10, pp 1623-1648

Agarwal, B. (2009). Gender and forest conservation: The impact of women's participation in community forest governance. Ecological economics, 68(11), 2785-2799.

Alexander, C., Bynum, N., Johnson, E., King, U., Mustonen, T., Neofotis, P., \& Vicarelli, M. (2011). Linking indigenous and scientific knowledge of climate change. BioScience, 61(6), 477-484.

Alston, M. (2013). Gender mainstreaming and climate change. Women's Studies International Forum.

Amwata D. A., D.M. Nyariki and N.K.R Musimba (2015). Factors influencing agro pastoral and pastoral household's vulnerability to food insecurity in the drylands of Kenya: A Case study of Kajiado and Makueni Counties. Journal of International Development, DOI: 10.1002.:3123.) 
Amwata, D.A. (2013). Assessing Climate Change Adaptation Strategies among Rural Maasai pastoralist in Kenya, American Journal of Rural Development. 2016, Vol. 4 No. 6, 120128

Berger, P. Rainfall and Agroclimatology of the Laikipia Plateau, Kenya; Geographica Bernensia: Bern, Switzerland, 1989; Volume A7.

Bhattarai, B., Beilin, R., \& Ford, R. (2015). Gender, agrobiodiversity, and climate change: A study of adaptation practices in the Nepal Himalayas. World Development, 70, 122-132.

Bryan, E., Ringler, C., Okoba, B., Roncoli, C., Silvestri, S., \& Herrero, M. (2013). Adapting agriculture to climate change in Kenya: Household strategies and determinants. Journal of environmental management, 114, 26-35.

Carrasco Miro, G. "United Nations Africa Human Development Report 2016: Accelerating Gender Equality and Women's Empowerment in Africa." (2016).

Christensen, J.H., B. Hewitson, A. Busuioc, A. Chen, X. Gao, I. Held, R. Jones, R.K. Kolli, W.T. Kwon, R. Laprise, V. Magaña Rueda, L. Mearns, C.G. Menéndez, J. Räisänen, A. Rinke, A. Sarr and P. Whetton 2007. Regional climate projections. In: Solomon et al. 2007, pp. 849-926.

County Government of Kajiado 2018. Kajiado County Integrated Development Plan 20182022. County Government of Kajiado. Pages 166.

County Government of Kiambu 2018. Kiambu County Integrated Development Plan 20182022. County Government of Kiambu. Pages 434.

Darkoh, M. B. K., Khayesi, M., and Mbaiwa, J. E. (2014) 6 Impacts and responses to climate change at the micro-spatial scale in Malawi, Botswana and Kenya. Local Climate Change and Society, 109.

Fraser, EDG, Dougill AJ, Hubacek K, Quinn CH, Sendzimir J, Termansen M. 2011. Assessing Vulnerability to Climate Change in Dryland Livelihood Systems: Conceptual Challenges and Interdisciplinary Solutions. Ecology and Society 16(3): 3.

Fratkin, E., \& McCabe, J. T. (1999). East African pastoralism at the crossroads: An introduction. Nomadic Peoples, 5-15.

GoK. 2010. National Climate Change Response Strategy. Ministry of Environment and
Mineral Resources. Government of Kenya. Nairobi, Kenya. GoK. (2010).

Government of Kenya (2019). Kenya National Bureau of Statistics (KNBS). Volume I: Population by County and Sub-County. Government of Kenya.

Hart, L. G., Larson, E. H., \& Lishner, D. M. (2005). Rural definitions for health policy and research. American journal of public health, 95(7), 1149-1155.

Hoffmann, I. (2010) Climate change and the characterization, breeding and conservation of animal genetic resources. Animal genetics, $41(\mathrm{sl}), 32-46$

Huho, J. M., \& Kosonei, R. C. (2014). Understanding extreme climatic events for economic development in Kenya. IOSR Journal of Environmental Science, Toxicology and Food Technology, 8(2), 14-24.

Huq, S., \& Toulmin, C. (2006). Three eras of climate change. IIED Opinion.

Ibarrarán, M. E., Ruth, M., Ahmad, S., \& London, M. (2009). Climate change and natural disasters: macroeconomic performance and distributional impacts. Environment, development and sustainability, 11(3), 549-569.

IGAD Climate Prediction and Application Centre (ICPAC). (2007). Climate variability and change and human development in Africa: Assessing the risk and vulnerability of climate variability and change in Kenya, Malawi and Ethiopia. ICPAC, Nairobi, Kenya Intergovernmental Panel on Climate Change (IPCC) 2014. Climate Change2014: Synthesis Report. Contribution of Working Groups I, II and III to the Fifth Assessment Report of the Intergovernmental Panel on Climate Change [Core WritingTeam, R.K. Pachauri and L.A. Meyer (eds.)]. IPCC, Geneva, Switzerland.

Jaetzold, R., \& Schmidt, H. (1983). Farm management handbook of Kenya: Natural conditions and farm management information.

Jaramillo, J., Muchugu, E., Vega, F. E., Davis, A., Borgemeister, C., \& Chabi-Olaye, A. (2011). Some like it hot: the influence and implications of climate change on coffee berry borer (Hypothenemus hampei) and coffee production in East Africa. PloS one, 6(9), e24528.

Jaramillo, J., Setamou, M., Muchugu, E., ChabiOlaye, A., Jaramillo, A., Mukabana, J., ... \& Borgemeister, C. (2013). Climate change or urbanization? Impacts on a traditional coffee 
production system in East Africa over the last 80 years. PloS one, 8(1), e51815.

Kauti, M.K. Rural Livelihood Security Assessment for Smallholders Undergoing Economic Changes and Agro-Climatic Events in Central Kenya; Research Institute for Humanity and Nature (RIHN): Kyoto, Japan, 2009.

KNBS - Kenya National Bureau of Statistics and SID - Society for International Development (2013) Exploring Kenya's Inequality: Pulling Apart or Pooling Together? Nairobi: KNBS and SID

Kenyatta J. (1938) .Facing Mount Kenya: The Tribal Life of the Gikuyu: Secker \& Warburg, 1938

KALRO-Kenya Agricultural and Livestock Research Organization (2012). Annual Technical Report for the Year 2012. Kenya Tea Research Institute. KALRO, 2012.

Kumar, N., \& Quisumbing, A. R. (2015). Policy reform toward gender equality in Ethiopia: Little by little the egg begins to walk. World Development, 67, 406-423.

Kuria, D. 2009. Coping with climate change: Understanding local communities' knowledge and their coping strategies to climate change. Birdlife International. Nairobi, Kenya

Macharia, P. N., Thuranira, E. G., Nganga, L. W., Lugadiru, J., \& Wakori, S. (2012). Perceptions and adaptation to climate change and variability by immigrant farmers in semi-arid regions of Kenya. African Crop Science Journal, 20(2), 287-296.

McHugh, M. L. (2013). The chi-square test of independence. Biochemia medica: Biochemia medica, 23(2), 143-149.

Meinzen-Dick, R., \& Mwangi, E. (2009). Cutting the web of interests: Pitfalls of formalizing property rights. Land Use Policy, 26(1), 36-43.

Mitchell, T., Tanner, T., Lussier, K., Burton, A., Khamis, M., \& Ross, S. (2007). We know what we need: South Asian women speak out on climate change adaptation. ActionAid International

Murage, A. W., \& Ilatsia, E. D. (2011). Factors that determine use of breeding services by smallholder dairy farmers in Central Kenya. Tropical animal health and production, 43(1), 199-207.

Muriuki, G. (1974). A history of the Kikuyu 15001900. Nairobi: Oxford University Press.

Musa, M. K., \& Odera, P. A. (2015). Land Use Land Cover Changes and their Effects on Food Security: A Case Study of Kiambu
County-Kenya. Kabarak Journal of Research \& Innovation, 3(1), 74-86.

Ngaina, J., and Mutai, B. (2013) Observational evidence of climate change on extreme events over East Africa. Global Meteorology, 2(e2), 6-12

Njuguna, E., \& Nyairo, N. (2010). Formal conditions that affect agricultural credit supply to small-scale farmers in rural Kenya: case study for Kiambu County.

Nyasimi, M., Amwata, D., Hove, L., Kinyangi, J., \& Wamukoya, G. (2014). Evidence of impact: climate-smart agriculture in Africa.

Oberhauser, A., \& Johnston-Anumonwo, I. (2014). Global Perspectives on Gender and Space: Engaging Feminism and Development. Routledge

Ogutu, J.O., H.P. Piepho, M.Y. Said, and S.C. Kifugo. 2014. Herbivore dynamics and range contraction in Kajiado County Kenya: Climate and land use changes, population pressures, governance, policy and humanwildlife conflicts. Open Ecology Journal 7: 931.

Opiyo, E. O. (2014). Climate variability and change on vulnerability and adaptation among Turkana pastoralists in North Western Kenya.

Orindi, V. A., Nyong, A., and Herrero, M. (2007) Pastoral livelihood adaptation to drought and institutional interventions in Kenya. Human Development Report Office, Occasional Paper, 54.

Pascual, M., Ahumada, J. A., Chaves, L. F., Rodo, X. and Bouma, M. (2006) Malaria resurgence in the East African highlands: Temperature trends revisited. Proceedings of the National Academy of Sciences, 103 (15), pp. 5829-5834.

Quiggin, J.; Adamson, D.; Chambers, S.; Schrobback, P. Climate change, uncertainty, and adaptation: The case of irrigated agriculture in the Murray-Darling Basin in Australia. Can. J. Agri. Econ. 2010, 58, 531554.

Recha, J. Kinyangi J. \& Omondi, H. (2012). Climate Related Risks and Opportunities for Agricultural Adaptation in Semi-Arid Eastern Kenya', Report on climate change, agriculture and food security, pp.40.

Swift J. (1998). Major issues in pastoral development with special emphasis on selected African countries. FAO Rome, Italy.

Talle, A. (2007). 'Serious games': Licenses and prohibitions in Maasai sexual life. Africa Journal, 77(3), 351-370. 
Thornton, P. K., Herrero, M. T., Freeman, H. A., Okeyo Mwai, A., Rege, J. E. O., Jones, P. G., \& McDermott, J. J. (2007). Vulnerability, climate change and livestock-opportunities and challenges for the poor.

Upadhyay, B., Samad, M., \& Giordano, M.

(2005). Livelihoods and gender roles in dripirrigation technology: A case of Nepal (Vol. 87). IWMI.

Wamue-ngare, and Njoroge. (2011). Gender Paradigm Shift within the Family Structure in Kiambu, Kenya Abstract.
Wasonga, V. O., Kambewa, D., \& Bekalo, I. (2010). Community-Based Natural Resourc e Management. Managing Natural Resources for Development in Africa: A Resource Book, 165.

Wasonga, V.O. (2009). Linkage between land use, land degradation and poverty in semiarid rangeland of Kenya.

Yamane, Taro. (1967): Statistics: An Introductory Analysis, 2nd Ed., New York: Harper and Row. 